\title{
浅论人力资源管理如何推动企事业单位高效运行实现社会经 济持续发展
}

胡诗思

桐庐县招投标服务中心

DOI:10.32629/ej.v2i5.223

[摘要] 人力资源管理与组织高效运行之间有着密不可分的关系,两者相互促进、相互融合,从而推动经济发展。为了达到组 织可持续发展的目的, 人力资源管理水平要与时俱进, 基于此, 本文概述了人力资源管理, 阐述了人力资源管理在企事业单位的 运行和社会经济发展中的重要性, 对人力资源管理推动组织内部高效运行和社会经济发展的措施进行了论述分析。

[关键词] 人力资源管理; 组织高效运行; 经济发展; 重要性; 措施

\section{1 人力资源管理的概述}

人力资源管理是指根据企业发展战略要求, 运用科学方 法有计划地对人力资源进行合理配置, 灵活使用现代管理方 法, 对人力资源的获取 (选人)、开发 (育人)、保持 (留人) 和 利用 (用人) 等方面所进行的计划、组织、指挥、控制和协调 等一系列活动, 调动员工的积极性, 发挥员工的潜能, 为企业 创造价值, 最终达到实现企业发展目标的一种管理行为。确 保企业战略目标的实现, 是企业的一系列人力资源政策以及 相应的管理活动。这些活动主要包括企业人力资源战略的制 定, 员工的招募与选拔, 培训与开发, 绩效管理, 薪酬管理, 员 工流动管理, 员工关系管理, 员工安全与健康管理等。

\section{2 人力资源管理在组织运行和经济发展中的重要性}

2.1 提升组织对外竞争力

企事业发展中的人才竞争力基础就是合理开发和利用 已有的人力资源和开发市场的人力资源为本单位所用。在目 前的市场经济竞争中, 企事业单位中的人才竞争力决定着企 事业组织发展的竞争力, 而人才的竞争力又体现在企事业的 人力资源管理水平。所以, 增强企事业人力资源管理是增强 核心竞争力的关键。在市场竞争中, 人才竞争不但是科技竞 争的核心, 也是科技竞争力的重要前提。因此, 企业想要把握 自己在市场经济竞争的主动权, 就必须占有市场经济中人才 竞争的主动权, 既要加大对人力资源的开发, 又要提高各种 人才的专业素质, 从而优化人力资源结构, 形成一支高层次、 高素质的人才团队, 同时也要注重对拔尖人才和创新人才的 培养, 只有这样才能提升企业人才的竞争力, 增强企业在市 场经济中的竞争力。

\section{2 是促进经济发展的重要动力}

不同资源要素的不断增加促进了经济的发展, 这些资源 优化再组合后提高了经济发展效率, 而人才是最终实施和实 现这些资源增加及优化组合的最重要的资源。因此, 经济提 高的效率及程度最终是由人力资源的质量来决定的。所以想 要经济得到不断发展, 就必须提高人力资源的质量, 而提高 人力资源质量就必须不断开发、提升人才的素质、综合能力
及核心竞争力。人力资源的合理开发利用不但可以为企业经 济发展提供智力保障, 还可以有效提高企业经济的资源配置 效率。

\section{3 有效推动经济发展中的产业结构升级}

产业结构升级可以有效带动经济的快速发展。在新的市 场经济竞争中, 想要独占鳌头, 就必须具有领先市场的高科 技产业, 而高科技产业的产出离不开人才的支持。所以说, 人才是决定企业发展效率的重要因素。高科技企业不但是人 力资源消耗系数最大的产业, 也是对高素质人力资源需求最 大的企业。因此, 必须加强对人力资源的开发与管理。因为 这是提高企业经济技术水平、企业经济升级换代、产业结构 科技水平提升的必须前提。

\section{3 人力资源管理推动经济发展的措施分析}

3. 1 树立正确的人才战略发展目标

知识经济时代下的人力资源管理需要从地区战略发展 目标出发。当前我国很多地区对人力资源开发的意识较模 糊, 忽略了地区的经济发展目标, 没有将人力资源与地区发 展相结合。地方政府必须意识到人力资源在区域经济发展 中的重要作用, 对地区的特点进行详细分析, 找出地区经济 发展的优势与不足, 在结合实际情况的基础上, 制定出具有 针对性的发展措施, 使人力资源的目标能够与地区未来的 发展趋势相结合。将人力资源的开发纳入地区经济开发的 规划过程中, 在指导地区经济发展的时候, 培养和储备更多 的专业型和综合型人才, 弥补人力资源开发中出现的短期 行为和现象。

\section{2 坚持以人为本的管理思想}

人力资源管理要坚持以人为核心, 对员工进行人性化的 管理。要在管理制度、管理方式、管理手段和管理网格上具 体体现出来。首先选好人才, 选才必须以德为本, 德才兼备, 以德为先。在此基礎上要重视人才和用好人才, 要有突破, 用人要不拘一格, 知人善任。要求管人的人, 要以身作则, 在 工作中, 既要尊重人才, 还需要奖惩分明。在注重人本管理的 同时, 要以制度的形式确立人才培养机制、激励机制、创新 
机制、风险共担机制等多种规范制度。制度建设也要人性化, 制定规章制度, 要通过实践总结和归纳, 做到具体可行, 这样 才能使制度发挥巨大的管理功效。人性化管理必须与制度化 管理结合起来才是最有效的管理, 人性化管理应当以合理的, 科学的制度为前提, 制度化是 “硬件”, 而人性化是 “软件”, “硬件” 只是基础, 而要运作更好, 效率更高, 则要有更好的 软件, 这就要求管理者要将人性与制度和谐统一起来, 逐步 实现人本管理。人本管理是制度管理的方向, 要达到制度与 人性二者的有机结合, 要求现代企业所建立的管理制度, 不 仅仅成为约束人的工具, 还应该成为尊重人的价值与尊严, 对人员进行科学合理的利用, 做到知人善任, 有利于发挥人 的积极性和创造性的保障。也就是制度必须合法合理, 且切 实可行。制度规范使人的行为有所遵循, 但企业管理并不能 完全取决于制度的强制性, 更主要地取决于个体的理性化程 度, 即对制度的认同、信任与尊重。以人为本的管理是对员 工的尊重和重视。

\section{3加强绩效管理及职业生涯管理}

绩效是指组织成员对组织的贡献或对组织所具有的价 值, 可以表现为工作数量、质量等结果, 也可表现为员工在实 现工作目标过程中的行为。绩效是公司发展的生命线, 绩效 管理就是通往卓越业绩的必由之路。绩效管理就是要定出合 理的目标, 并通过绩效评价, 要求对员工日常工作行为和结 果进行监控, 对员工的行为具有导向功能。职业是指人们在 社会生活中所从事的以获得物质报酬作为自己主要生活来 源并能满足自己精神需求的社会分工中具有专门技能的工 作。是社会与个人或组织与个人的结合点, 这样一个合适的 职业, 度过一段成功的职业生涯是每一个人追求和向往的。 对企业而言, 不同工作岗位要求具有不同能力、素质的人担 任, 合适的人放在合适的位置上, 是人力资源管理的重要职 责。选拔人才, 必须要独具慧眼多加考察, 充分认识员工各方
面的素质, 综合评估员工能力, 给员工安排适合的职位, 选 准人才。管理者要了解员工, 信任员工, 放手让他去干, 作为 一个管理者, 信任是网罗人心, 推动上下级关系的一大法 宝。管理者要有在任何时候, 树立 “做正确的事” 的管理思 想, “做正确的事” 是由团队战略来解决的, 强调的是绩效, 与 “正确的做事” 是有区别的, 后者则是强调效率。前者强 调的是绩效, 也是企业经济发展的根本。现代人力资源管理 理念认为, 绩效考核是一种开放发展的方式, 不仅是有 “回 顾性” , 关键在于 “展望性”。对员工来说提高了个人人力 资本的投资收益, 使自我价值不断提升和超越, 降低了改变 职业通道的成本。对企业来说, 使资源可合理配置, 充分调 动人的内在积极性, 建立创造和谐的人际关系, 提高团队的 凝聚力、向心力和执行力, 更好地实现企业组织目标, 以保 证企业的不断发展。

\section{4 结束语}

综上所述, 人力资源管理是企事业单位能得以长期发展 的前提条件, 其可以使企事业单位能够充分利用人才、把握 人才、尊重人才, 使各自在岗位上为企事业单位创造价值。 因此必须做好人力资源管理工作, 从而推进社会经济可持续 发展。

[参考文献]

[1]郭印生.人力资源管理与经济可持续发展研究[J].人 力资源管理,2017(07):1.

[2]汪鸿. 人力资源管理推动经济发展的探索 [J]. 中国商 论,2019(02):255-256.

[3]张雪艳,王艳. 人力资源管理推动经济发展的探索 [J]. 中外企业家,2019(13):111.

[4]董克用, 叶向峰编著. 《人力资源管理概论》[M].中国 人民大学出版社出版,2003(9)7-10. 